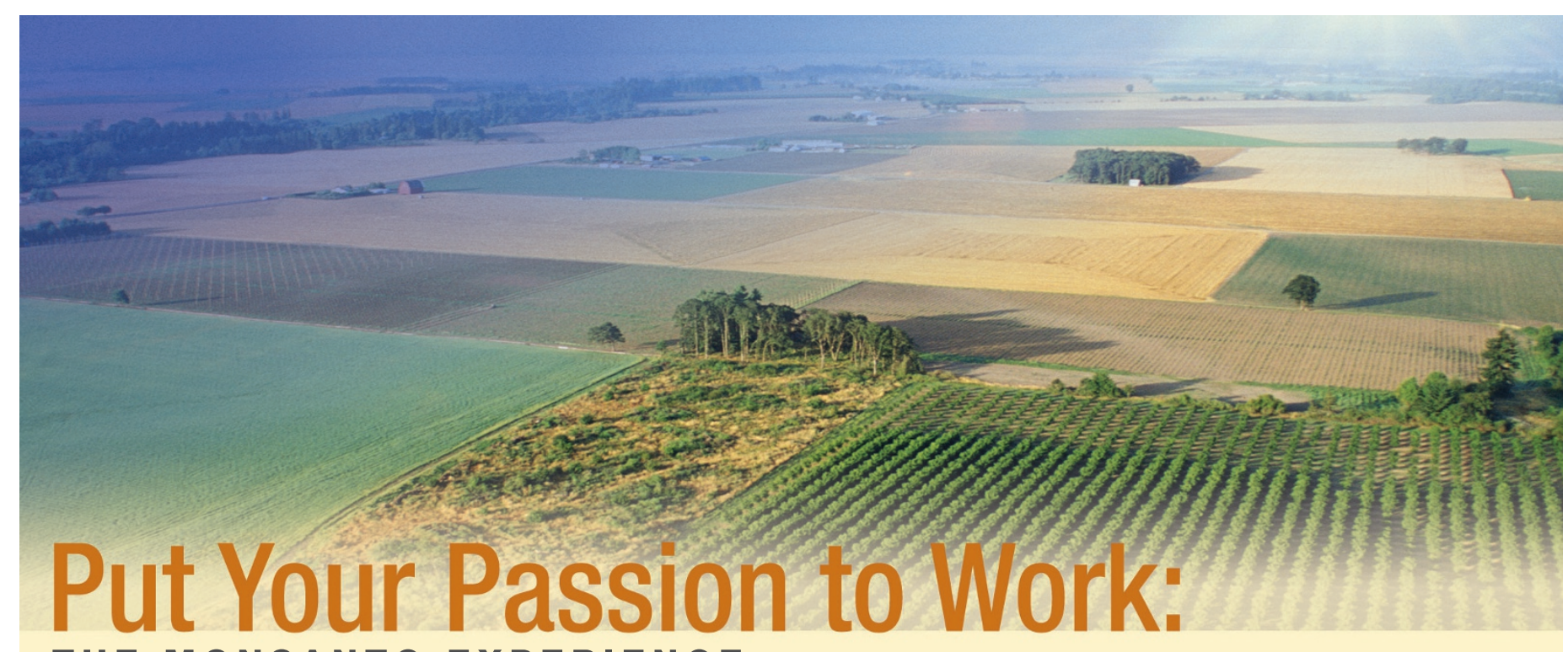

\title{
THE MONSANTO EXPERIENCE
}

At Monsanto, we're passionate about using science and technology to improve agriculture. We invest about $\$ 1.5$ million a day to look for and bring to market the innovative technologies that our customers tell us make a difference. It's research that's about more than just biotechnology. We use many tools - like genomics, conventional and molecular breeding, crop analytics, animal productivity, chemistry and biotechnology - to bring forward new products to answer our customers' needs, in turn, providing benefits to not only the farmer, but processors and consumers, as well.

At Monsanto, we believe in -

\section{INNOVATION IN AGRICULTURE}

Advanced science and innovative technology are at the heart of our company. We are committed to developing science based solutions to make our farmer customers more productive and profitable. Our employees are making a difference by feeding the world while preserving the environment.

\section{EX C ELLENCE}

People at Monsanto are driven to do extraordinary things and are dedicated to being the best in our industry.

\section{GREAT WORKING RELATIONSHIPS}

Monsanto is team based with highly qualified professionals sharing knowledge, creating a great place to work and allowing employees to take ownership for results.

To learn more about Monsanto, our passion and our opportunities, visit www.monsanto.com.

\section{Come grow with us.}

\section{O N S A N T O imagine}

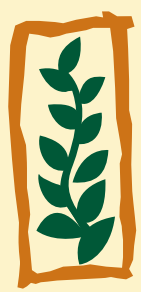

Monsanto values diversity and is an equal opportunity affirmative action employer. M/F/D/V 


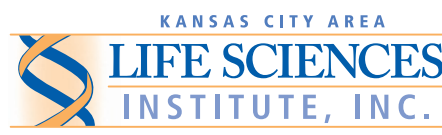

Advancing the development of the life sciences community within the Kansas City region

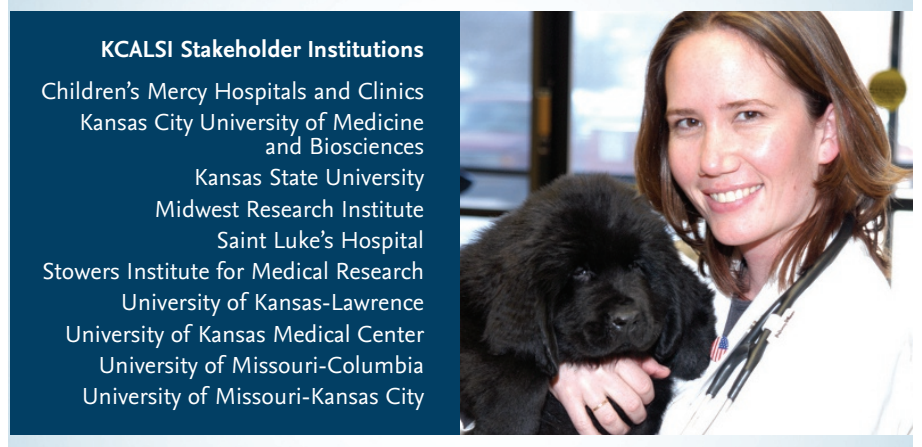

The Kansas City area is the source of many exciting new discoveries in life sciences research, and is home to the KC Animal Health Corridor, the global leader for animal health and nutrition research, innovation and production.

PHONE (816) 753-7700 www.kclifesciences.org

NW126911A
UNIVERSITY OF MISSOURI-KANSAS CITY Leaders in health sciences research and education

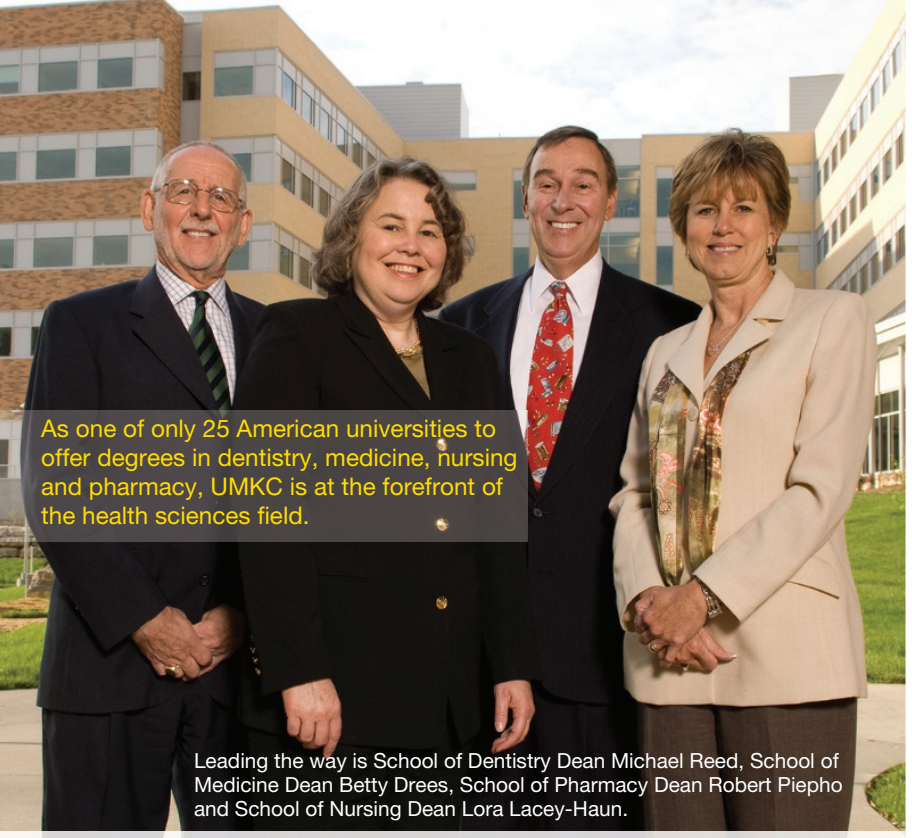

UMKC UMKC is an equal opportunity/affirmative action institution.

\section{Lost in today's ever-changing}

\section{biosciences environment?}

...get your bearings with these Stanford School of Medicine Career Center (SoMCC) seminars presented by Naturejobs.

Naturejobs and the Stanford School of Medicine have collaborated to bring you this video series featuring SoMCC "Industry Insights" and "Careers in Science" programs. This monthly series,

delivered by top experts within the biomedical sciences and healthcare industries, will allow you to:

- OBTAIN OF THE LATEST TRENDS AND FORCES SHAPING THE BIOSCIENCES GAIN VISIBILITY INTO THE DIVERSE SETTINGS WHERE BIOMEDICAL PROFESSIONALS ENGAGE

LEARN FROM FIRST-HAND PERSPECTIVES OF THE FOREMOST LEADERS IN BUSINESS AND ACADEMIA

Visit www.naturejobs.com/magazine/video to stream or download the following presentations:

- Convergence of Science, Banking, and Finance with MDS Capital, Nandini Tandon, Ph.D MDS Capital

- How Should We Be Developing Drugs in the 21st Century?, Hal Barron, MD, Genentech

And stay tuned for these seminars coming soon:

- Intellectual Property Management \& Technology Transfer, Panel of Experts

- Science \& the Media, Donald Kennedy, PhD, Emeritus Professor, Stanford

- The Future of Personalized Medicine, with Agilent Technologies

If you are interested to learn more about the SoMCC, please contact Suzanne Frasca, Program Coordinator, at (650) 725-7687 or somcareers@stanford.edu
naturejobs

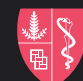
Stanford Medical School

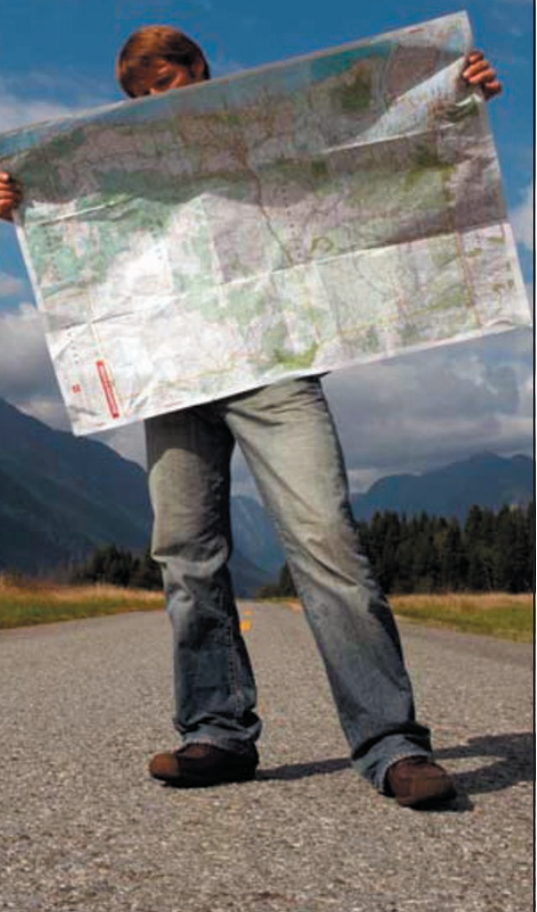




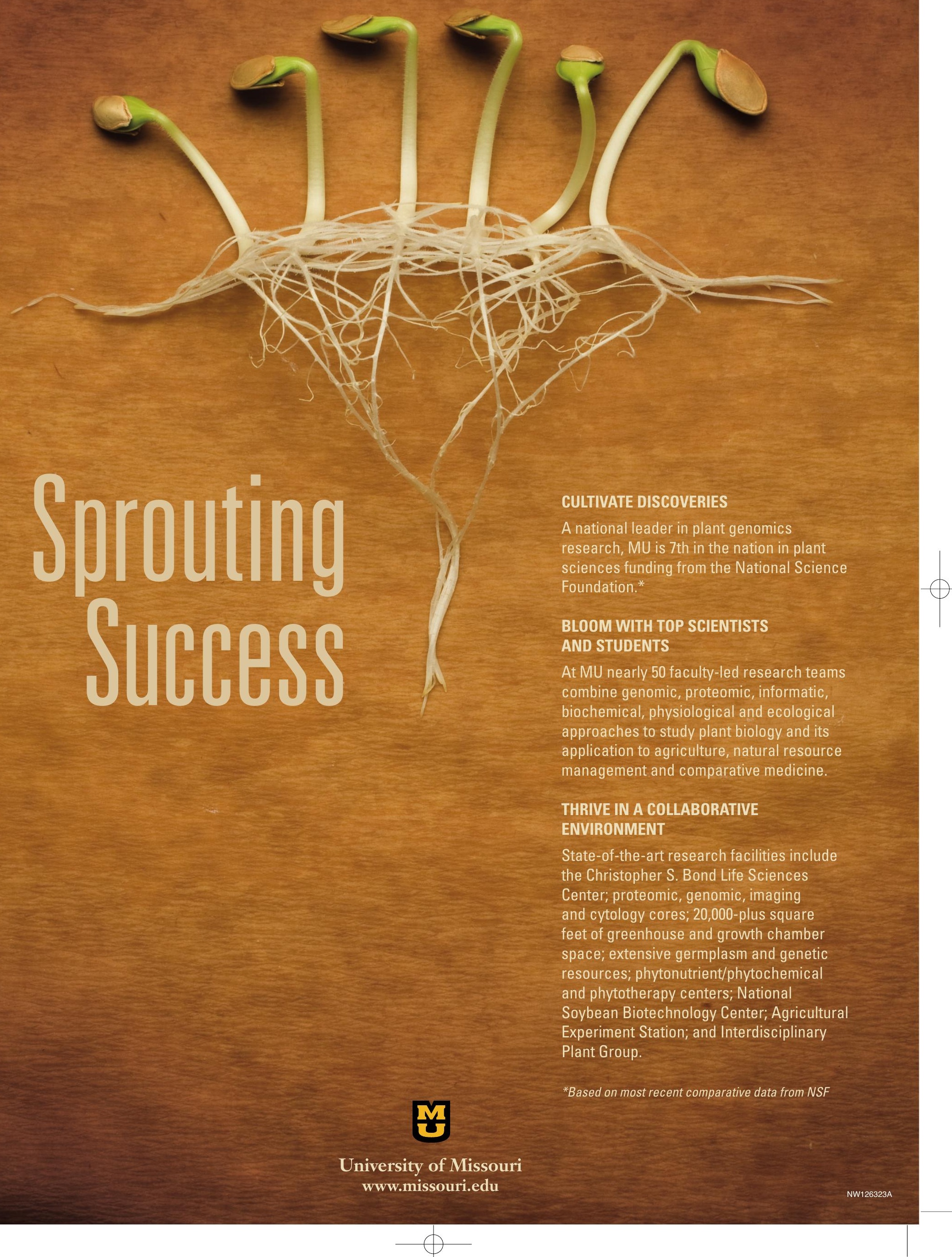




\section{FACULTY POSITION IN CARDIOVASCULAR BIOCHEMISTRY \\ DEPARTMENT OF BIOCHEMISTRY AND MOLECULAR BIOLOGY \\ SAINT LOUIS UNIVERSITY SCHOOL OF MEDICINE}

Saint Louis University, a Catholic Jesuit institution dedicated to studen learning, research, health care, and service is seeking applicants for a faculty position in the Edward A. Doisy Department of Biochemistry and Molecular Biology for a tenure-track position involving research and teaching at the ASSISTANT PROFESSOR level, although outstanding candidates at a more senior level will be considered. The department is housed in the E.A. Doisy Research Center, a brand new state-of-the-art facility designed to foste collaboration between investigators. We seek applicants who use innovative approaches in the areas of cardiovascular biology, metabolism and signaling. Cardiovascular research is a growing focus area at the School of Medicine with strengths in lipidomics, cell signaling systems biology and molecular basis of cardiovascular disease. We are interested in a highly interactive candidate whose interests will complement ongoing research programs in the cardiovascular sciences in the Department as well as the University.

The successful candidate is expected to establish a strong extramurallyfunded research program. A potential for or demonstrated evidence of competing successfully for external funding will be important criterion for selection. Excellent start-up funds and salary are available. Interested candidates must submit a cover letter, application and current curriculum vitae to http://jobs.slu.edu. Additionally send current curriculum vitae, description of research plans, and at least three letters of recommendation to:

Search Committee

c/o William S. Sly, M.D., Chairman

Edward A. Doisy Department of

Biochemistry and Molecular Biology Saint Louis University School of Medicine

1100 South Grand Blvd.

St. Louis, MO 63104-1028

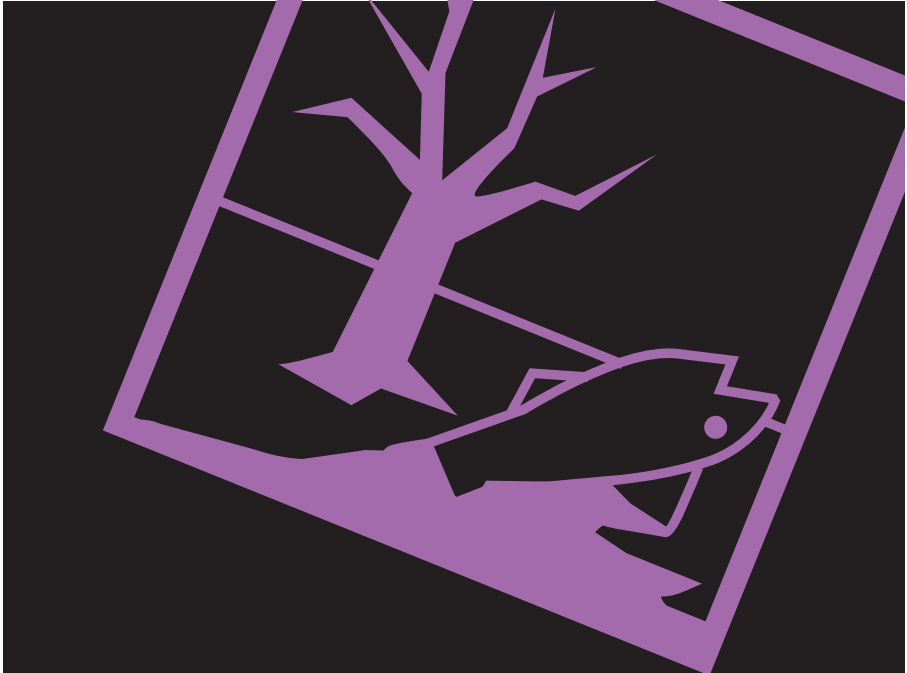

\section{Change your}

\section{environment. Find}

jobs where you'll

\author{
make a difference
}

\section{naturejobs}

\section{Scientific Training}

at Washington University in St. Louis

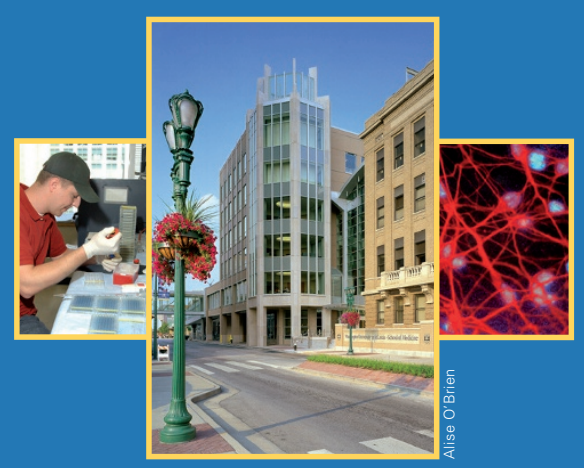

Interdisciplinary research that shapes the future

Opportunities in:

Undergraduate Summer Research: biomedrap. wustl.edu Graduate Programs: dbbs. wustl.edu

Medical Scientist Training Program: mstp.wustl.edu

Postdoctoral Training: dbbs.wustl.edu/postdoc

Washington University in St.Louis Brology \& BIOMEDICAL SCIENCES

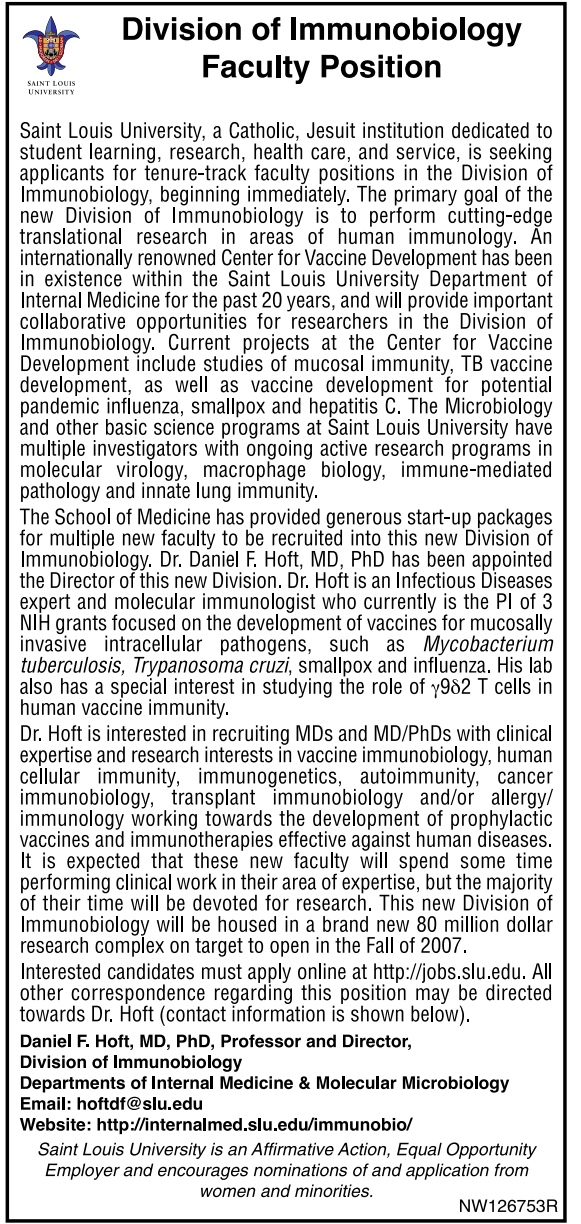

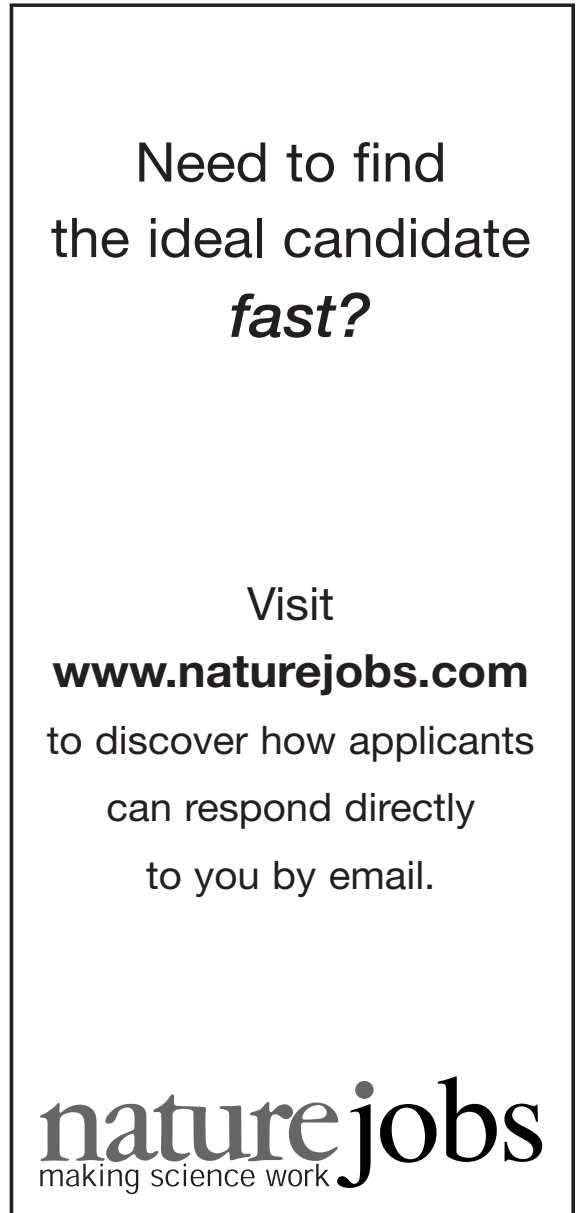

